\title{
INTERDISCIPLINARY TEAM TEACHING
}

\section{FENOLLERA, M.; LORENZO, J.; GOICOECEHA, I. \& BADOUI, A.}

Abstract: In this study a team teaching approach was assumed as pedagogical principle for elaboration of the curricular proposal in Structural Engineering, gathering together the professionals and the different areas of the knowledge. The proposed collaboration model provides a viable way of enabling lecturers and students to carry out and to harvest the benefits of student-centered learning.

For the curricular projects' elaboration, multidisciplinary equipment was constituted, made-up of six lecturers of two diferent area of knowledge. The different roles of educators are deeply discussed, new applied methodologies and teaching techniques are introduced as well as a Project-Based Learning (PBL) model.

The results obtained, as much in the teaching process like in the academic results will be presented. The encouraging results obtained in two years guarantee studies to longer term, which nowadays already is realized.

Key words: team teaching, collaboration, interdisciplinary, project-based learning, professional competence, structural engineering
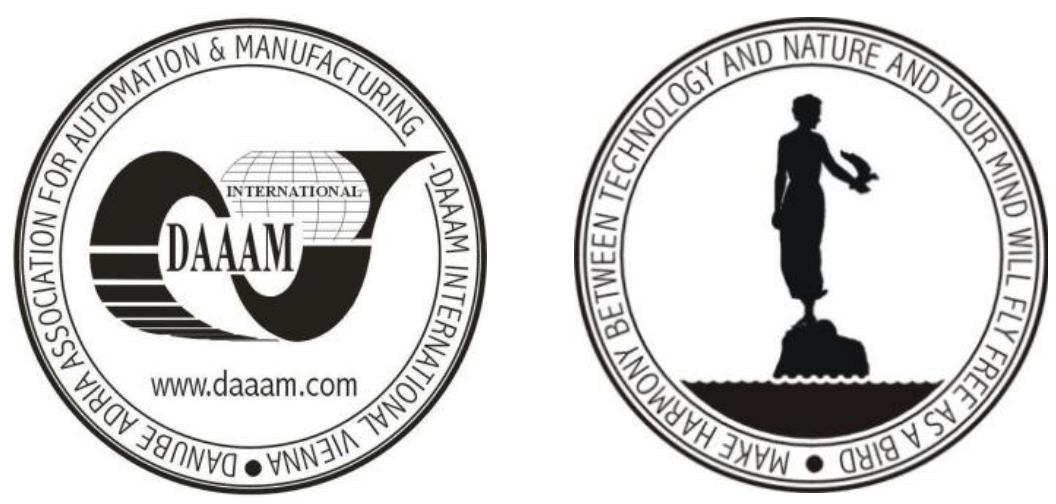

Authors' data: Univ. Prof. Eng. Fenollera, M[aria]; Univ. Prof. Eng. Lorenzo, J[aime]; Dr. Eng. Goicoechea, I[tziar]; Dr. Eng. Badoui, A[ida], University of Vigo, School of Industrial Engineering. Campus Lagoas Marcosende s/n Vigo. Spain, mfenollera@uvigo.es, jaimelorenzo@uvigo.es, igoicoechea@uvigo.es,aida@uvigo.es

This Publication has to be referred as: Fenollera, M[aria]; Lorenzo, J[aime]; Goicoechea, I[tziar] \& Badoui, A[ida] (2012). Interdisciplinary Team Teaching, Chapter 49 in DAAAM International Scientific Book 2012, pp. 585-600, B. Katalinic (Ed.), Published by DAAAM International, ISBN 978-3-901509-86-5, ISSN 17269687, Vienna, Austria

DOI: $10.2507 /$ daaam.scibook.2012.49 


\section{Introduction}

Buckley (2000) cautions that there is no universal approach to team teaching and provides this definition: "Team teaching involves a group of instructors working purposefully, regularly, and cooperatively to help a group of students learn'. This approach is heavily dependent upon teaching styles, learning philosophies, interpersonal skills, shared experiences, and licensure status.

Team teaching offers several advantages over traditional single-teacher teaching method, including the provision of multiple learning perspectives, reduction of teaching redundancy, and the promotion of teamwork and communication between teachers. On the other hand, a disadvantage of team teaching is the potential conflict arising from variations in teaching styles and procedures. Carefully listening to the perspectives of team members are important starting point in resolving conflict (Chang \& Lee, 2010).

Implementing a team teaching approach requires administrative encouragement, acceptance of an initial experimental quality, and willingness to take risks (Villa, Thousand, \& Nevin, 2008). An important variable to consider, that play a crucial role in the success of the team, is whether the inception of the team teaching plan originated from the administrators or from the lecturers. This experience did not originate from administration; instead it evolved from the educators themselves.

Instead of memorizing facts and data that easily becomes obsolete, the learning process has to allow the development of the methodological knowledge and analytical skills, skills needed for learning to think and to analyze information independently (Popescu, 2011). Under these perspective, lecturers of Structural Engineering belonging to the University of Vigo have worked together in a co-active and coordinated framework, designing an effective syllabus, with the general mission to review and to adapt the subjects, and according to the keys of learning by competences. They have developed and planning the work of the student in a twoyear teaching experiment: 1st Stage in the 4th year subject "Structural Theory and Industrial Structures", and 2nd Stage in the 5th year subject "Engineering Projects", in 2009/2010 and 2010/2011 Academic Years.

\section{Theoretical framework}

Team teaching is one variation of co-teaching. For the purpose of this research, team teaching (Sandholtz, 2000; Welch \& Sheridan, 1995) and co-teaching (WaltherThomas et al., 1996) will be used interchangeably to identify a classroom with two or more teachers who share lessons planning, team-teaching practice and evaluation responsabilities (Syh-Jong, 2008). Enhancing the definition presented, a collaborative teaching team may be defined as two or more people who agree to:

- Coordinate their work to achieve at least one common, publicly agreed-on goal.

- Share a belief system that each of the co-teaching team members has unique and needed expertise.

- Demonstrate parity by alternatively engaging in the dual roles of teacher and learner, expert and novice, giver and recipient of knowledge or skills. 
- Use a distributed functions theory of leadership in which the task and relationship functions of the traditional lone teacher are distributed among all co-teaching group members.

- Use a cooperative process that includes face-to-face interaction, positive interdependence, performance, as well as monitoring and processing of interpersonal skills, and individual accountability.

In the literature, we find documentation of team teaching in single courses, across a program, and institution-wide (Perry \& Stewart, 2005), particularly since many new programs/courses emerge out of more than one traditional discipline, faculty members find it necessary to combine their expertise in order to adress the needs of those courses or programs (Kulynch, 1998). Collaborative teaching can also happen when faculty work together planning several classes as "cluster courses" (Dugan \& Letterman, 2008). In this case one course serves as a base for another course matching each of the disciplines to be taught, so a close multidisciplinary collaboration becomes necessary.

\section{Proposed teacher collaboration model}

One of the most intensive collaborative experiences is "team teaching" a course with one or more colleagues. For this experience, six lecturers $(2 \mathrm{PhD}, 2$ assistant and 2 associate professors), three of each area, who possess distinct and complementary sets of skills, combine roles and share resources and responsibilities in a sustained effort while working towards the common goal of academic success. The team members share planning, but each instructor teaches his own specialized skills area to the whole group of students.

This equipment was in charge of the systematization of the discussed ideas and to lay the theoretic and methodological foundations. Being conscious of that the proof that team teaching works comes not only from the lecturers' self-judgment, but from students' evaluations, and with the double objective of, on the one hand to help students feel more engaged, and on the other to make more sense of how this two subjects are interrelated, they happened to share an office and learned that they also shared common beliefs about learning and students.

In groups like this, when the team is larger than two or three members, a team leader is needed. It was decided by voting that the team leader is the coordinator of the Engineering Projects Area. She is in charge of internal operations of the team, such as setting up meetings and coordinating schedules, and is also responsible for external operations, for example communicating with department heads to ensure that the team is meeting departmental goals or that the resources and support are in place. The role of each team member is to participate in team discussion and planning sessions. The members must act responsibly and follow through on decisions made by the team within the timeframe decided upon by the team.

The first trouble considered prior to implementation was that the team members should have sufficient professional development in the area of team teaching; they should understand the philosophy behind team teaching and the 
rationale of how it will fit with the rest of the departmental program. Team teaching partners need time to foster a trusting and open relationship in which team-building discussions are encouraged, and as well they need to be clear about their responsibilities and the time requirements involved with their particular form of team teaching.

The team constituted themselves and developed for about a year before implementing the curricular proposal. At the beginning weekly meetings and then monthly were realized to make important decisions about: what will be presented (the units, lesson objectives), how the material is to be presented (to a large or small group presentation), who is to present the information, how the students will be assessed, and how small groups will be organized and which team teacher will be assigned to each small group. Following implementation of the team teaching program, lecturers continuing to identify, implement and analyze the variables needed for every student to succeed.

The second trouble considered deals with tension and conflict. Even when team teachers are great friends, as in this case, team teaching situations are seldom without conflict. The challenge is turning such conflict or tension into a constructive learning situation in which the differences between partner teachers can be used to improve their team teaching instead of corrupting it. The team teaching case of study is a group work and as such teams need to develop as functioning groups. In dealing with other team members teamwork is seldom without conflict, professional or personal points of view may clash. The great challenge they have been to face was to be able to blend differences constructively. To do this it was important to acknowledge team members' strengths, interests, personal and professional goals both in assigning responsibilities and in the conduct of meetings.

Being preoccupied with the details of syllabi planning, with the content of the teaching programme and with the range of education strategies adopted, perhaps the most critical trouble has not been taken into consideration, to take a broader view of the role of the teacher. These roles include helping students grow in understanding, knowledge, self-awareness, moral development and the ability to relate to others. Simultaneously the teachers are mangers of learning, curriculum designers, facilitators, counsellors, evaluators and, reluctantly, disciplinarians. To the best of their ability, they modulate across roles accordingly to individual and group needs as they select and create learning experiences for all their students.

\section{Courses design, description and analysis}

Within the framework of the Communique of the European Higher Education Area, the development of professional competence has been set as the primary object of the 21st century European universities (Heitmann, 2005; Helle, Tynjälä \& Olkinuora, 2006). Our objective in this multidisciplinary experience is to offer students the possibility of working in problems that simulate, as faithfully as possible, the interdisciplinary industrial environment.

Learning new structure calculation methods used in the analysis of engineering problems, is not an easy task. Traditional teaching methods, highly appropriate for 
introducing crucial structural concepts, are insufficient to show the power of analysis techniques overwhelmed by the complexity and ambition of today's engineering and architectural projects. The educator cannot develop complicated examples because the commonly used tools are not suitable to show the wide range of matrices and operations involved in the numerical resolution of problems. Therefore, the teacher is forced to solve very simple structures that are not the most appropriate for assessing the effectiveness of numerical methods. Moreover, not dealing with real-world examples that stimulate students and justify the use of such methods is not very attractive from the student's perspective.

The main purpose of this work is to remove the impediments mentioned as far as possible and to offer a practical complement by means of the most requested professional software that enables to continue and to solve rather important questions that cannot be developed on a whiteboard or written text. The proposed Syllabus presents contents interconnected at a theoretical and practical level starting from a project's development using market-leading CYPE Ingenieros, S.A. calculation and design of structures programs.

\subsection{Subjects}

The following courses outline the experimental setup and procedure:

\section{Structural Theory and Industrial Structures, 4th year subject}

It is a compulsory 6-credit subject ( 3 theoretical and 3 practical), taught during the first quarter (September-February). The number of students enrolled is about 340.

This stage, necessary in order to introduce the next one successfully, was implemented during the 2009/2010 academic year and continued in 2010/2011. New applied methodologies and teaching techniques are introduced, as well as a 'hands-on' approach of theoretical lectures that include field courses and field trips to real premises.

The subject is planned as a theory-based nucleus in which a series of classic analysis methods, like the Navier-Bresse method, the Castigliano method or the Three Moments method are imparted, as well as the study of numerical methods appropriate for implementation as the Matrix Methods for bar structures and the Finite Element Method for continuous structures. These thematic sections are put forward in master class together with small exercises for practical applications of the theory. Additionally, the subject includes a practical section, with guided tours and tutored work. The student will be evaluated in this subject by a final written exam.

As discussed earlier in this section, compulsory field courses are planned, where the student can observe and discuss with the lecturers and professionals of the sector about the different forms and types of constructions previously introduced in the subject's theoretical part. With this purpose, a first guided tour of "Castelo Soluciones Estructurales" premises takes place (Figure 1). This company, located in Industrial Park of As Gándaras (in Porriño), is active in the manufacture of prefabricated structures, and it is one of the largest producers in Spain and Portugal. It is at the forefront of precast concrete engineering and metal structures, developing 
innovative solutions and its own patents. It has been selected because it is closely linked to the University of Vigo, both regarding research and teaching.
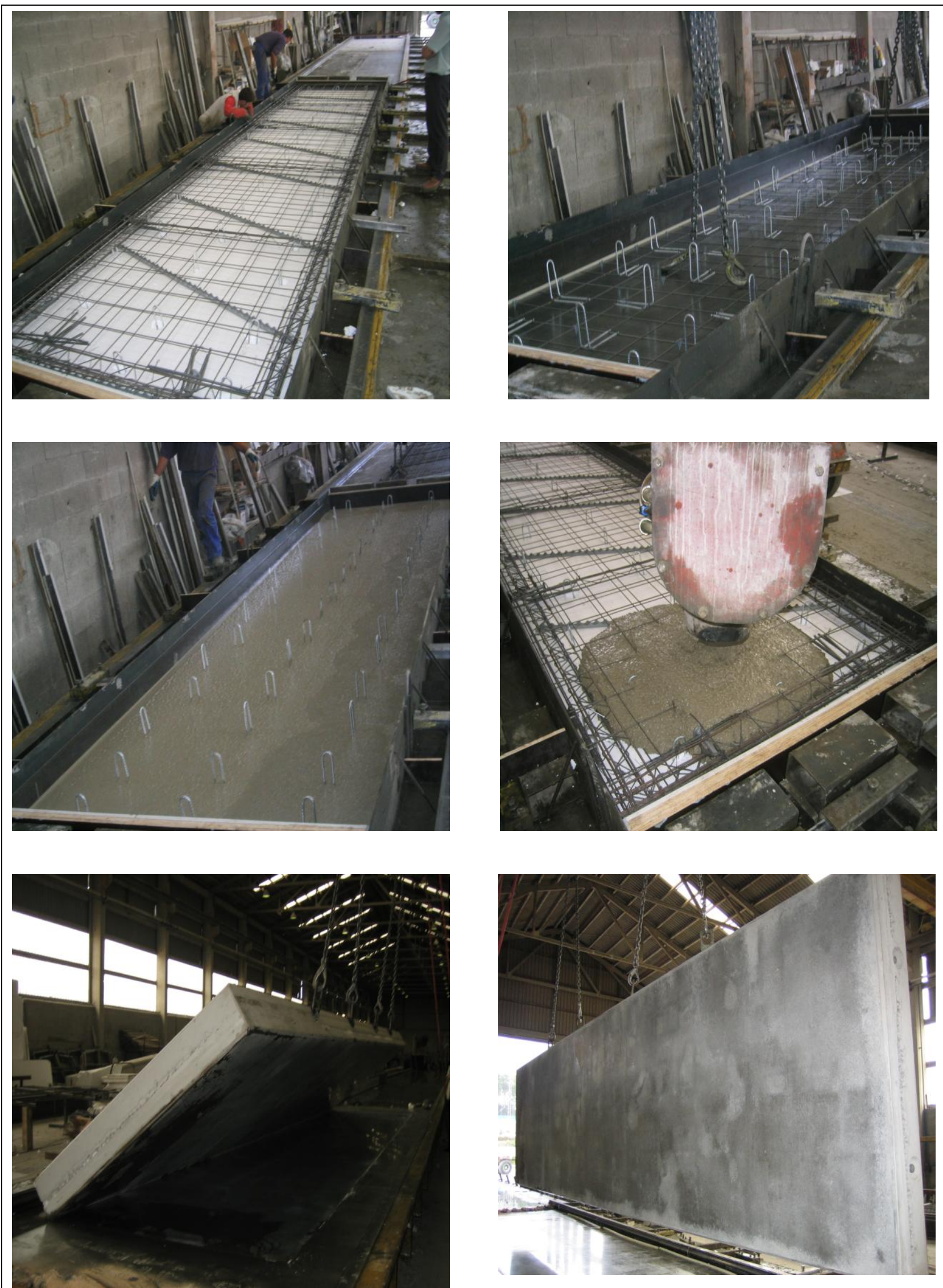

Fig. 1. Interior views of Castelo Soluciones Estructurales production plant 
The workshop areas are visited: processing and forming, prefabrication and assembly, and the laboratory, where students are explained the conditions for using the structural elements manufactured there; the different strength tests of actual pieces and concrete specimens; the situation and interaction with other elements involved in the process, what gives them a clear overview. Students receive detailed information about the structure itself, operating parameters, applied technology and multiple particular issues of structures. The training is supported by others guided tours to unique structures being built (Figure 2) where they can witness first hand a construction project.

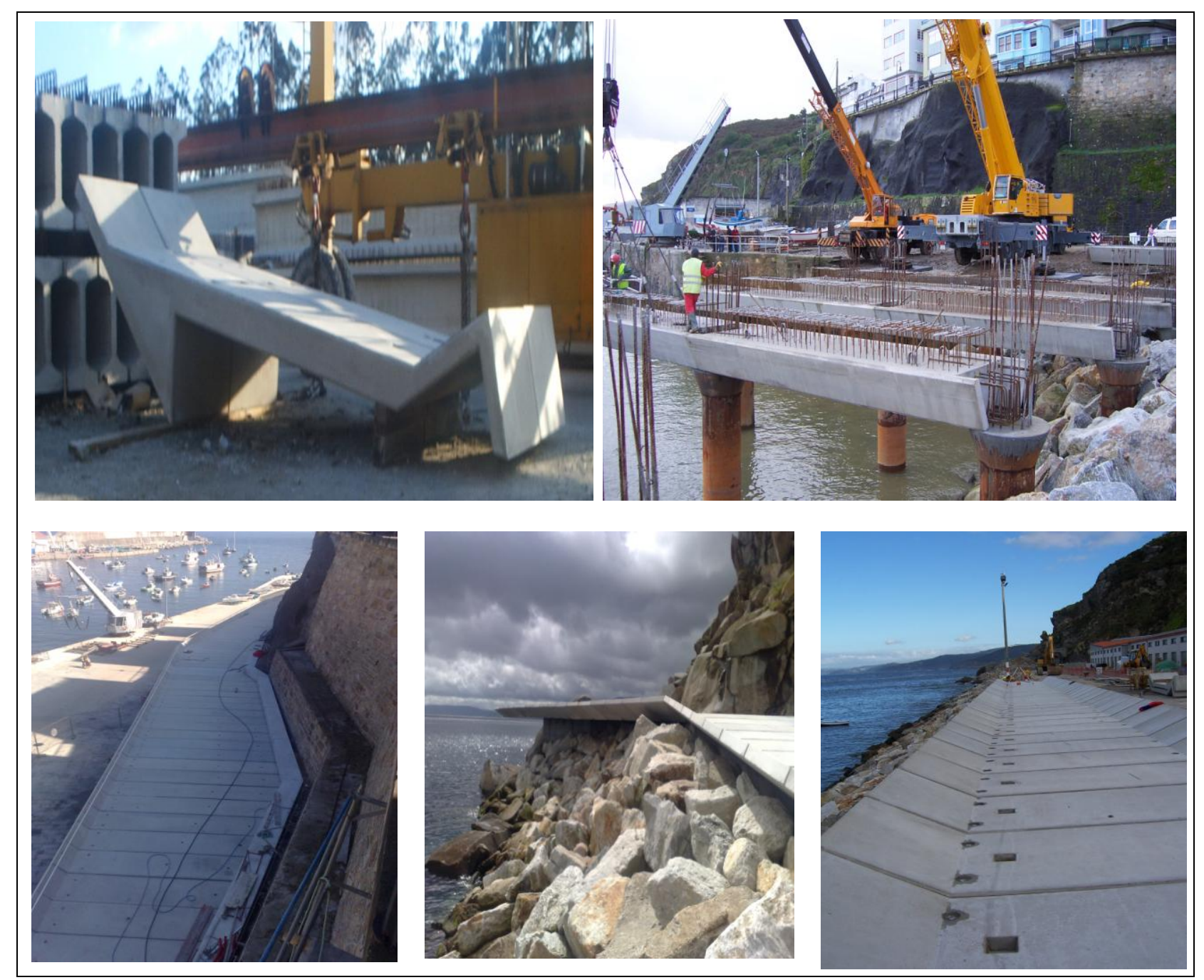

Fig. 2. Malpica (A Coruña) port view. A precast concrete jetty is being built on-site

This first stage is chiefly an example of a lecture situation where lecturers (1 $\mathrm{PhD}$ and 2 associate professors) are seen as an expert who are knowledgeable in his field. The lecture remains as one of the most widely used instructional methods. This leads to the traditional role of the teacher as a cost-effective method of providing new information to the local curriculum and context and of providing the lecturers' personal overview or structure of the field of knowledge for the student.

However, in accordance with the directives of the EHEA, the teachers also choose to adopt a more interactive approach, providing the students with some information but at the same time encouraging them during the lecture to engage with 
the subject and come up with their own solutions to problems posed. The increasing availability and use of learning resource materials also brings with it the need for the teacher as a learning facilitator. No set of course materials, whether in print or electronic format, is perfect for all students. It is the responsibility of the teacher to facilitate the student use of the resources by overcoming any deficiencies in the materials and by integrating them with the curriculum.

Because of this the lecturers, mainly the associate professors who are in permanent contact with the professional engineering world, cannot escape from being a role model, with how he approaches the subject and the attitudes he reveals influencing the student. Role modelling is widely recognise as critical in shaping, teaching, coaching and assisting future engineers as it is the most powerful teaching strategy available to engineering educators.

\section{Engineering Projects, 5th year subject}

It is a compulsory 6-credit subject: 3 theoretical and 3 practical, taught during the second quarter (February-July). The number of students enrolled is about 110.

At this stage a model of Project-Based Learning (PBL) as a learning strategy is implemented, using Cype calculation software. This model has been recognized by its role in the enhancement of professional and vocational abilities and has been described as successful strategy for instruction in a variety of contexts (Collis, 1998; English \& Yazdani, 1999; Goicoechea \& Fenollera, 2011). Based on pedagogical learning schemes inherent to learning, the following educational sections have been designed: theoretical lectures, laboratory practice and project.

- Theoretical lectures: starting from the knowledge acquired in the previous year subject, theoretical lectures are firstly presented as a quick revision of the subject basic concepts. Structural elements are then dealt with. Theory consists of a set of files that students can access anytime to solve practical doubts. Theory files have short explanations, providing the clues and ways to develop complex questions that can be found in books and in the Virtual platform of learning.

- Laboratory practice: during successive classes, students divided into four student groups of 25 and assessed by the teacher, make a simple calculation regarding an industrial building with an office building annex. Programs used are: CYPECAD for the concrete office building, and NUEVO METAL 3D for the metallic industrial building (Figure 3).

Step by step the real structural problem is solved: legislation in force, calculation assumptions, loads to be applied, calculation constraints, drawings, stress obtained in the different sections and their interpretation, analysis of behaviour of structures verifying the fulfilment of Ultimate and Service Limit State verification in accordance with Spanish Building Code. The university has provided each student with a licensed for educational use computer installed in computer rooms. Moreover, Cype offers the open access After Hours version with time constraints basically for use by students outside university hours. 


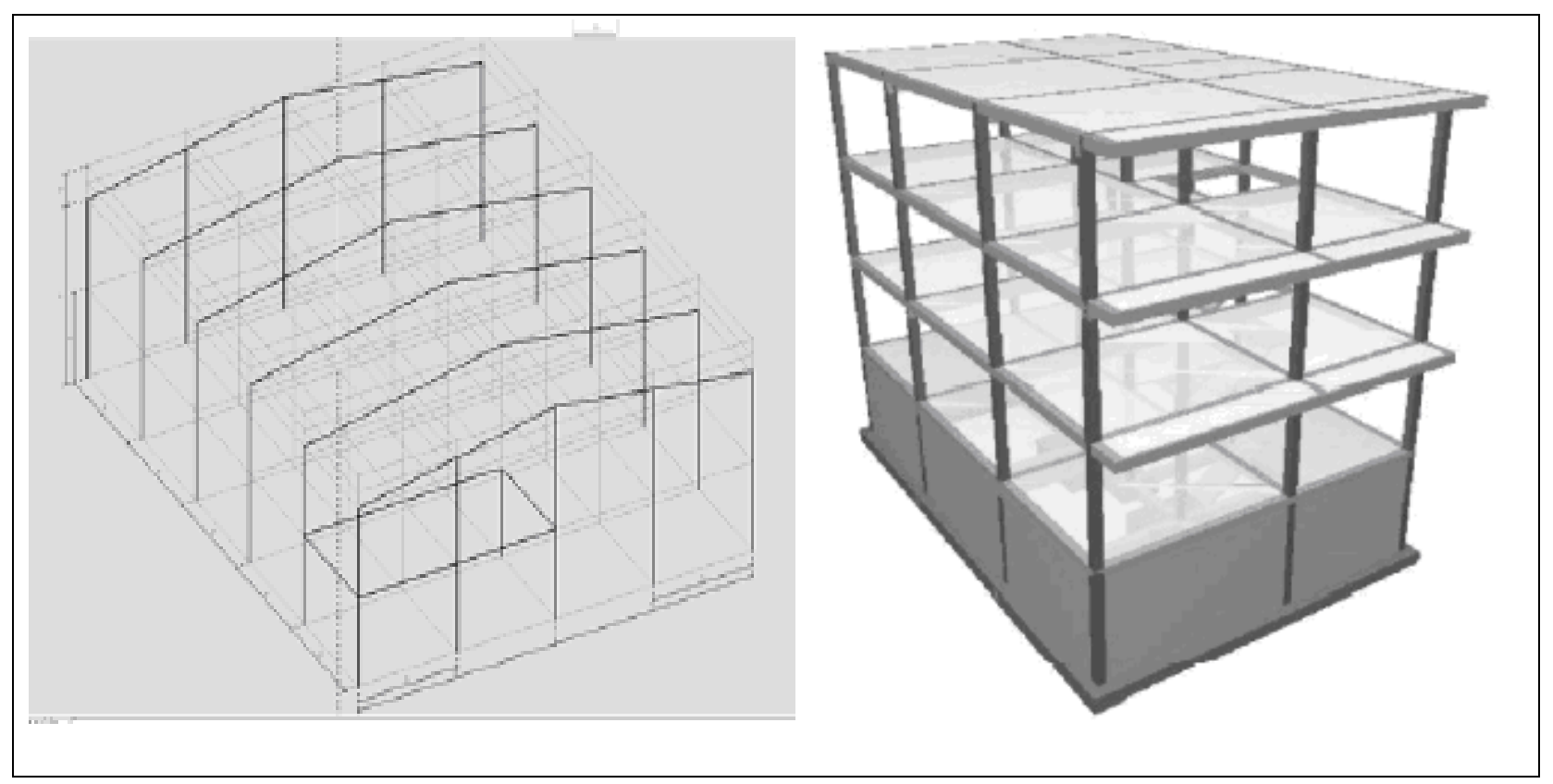

Fig. 3. Left: Metallic industrial building calculated with NUEVO METAL 3D. Right: Office building calculated with CYPECAD

- Project: The aim for the student is to show that he has assimilated the concepts, facing the solution to a real project. The teaching methodology used is the PBL in which students assume more freedom of action and responsibility and the teacher guides him in the learning process. We had in mind that the proposed Project fulfilled the characteristics that an appropriate PBL problem must have: it has to be relevant and of interest for students, have clear objectives and stages, and it has to be complex in the sense of having different solutions and an interdisciplinary nature. At this point we considered making a basic and implementation of an industrial building. 3-4 student groups are established. Each project team must establish the organizational functions, powers and responsibilities according to ISO standards within "the entity in which play the activity as Engineer".

Requirements are chosen by the group: choosing a municipality of Galicia; awareness of urban development laws; selecting an activity for the industrial building; classifying it; finding a land for construction in that council, designing the industrial building, measures, constructive elements, calculate it with Cype, prepare budgets... although they are to be validated by the teacher. Once defined, they must be maintained throughout the project. The Working Plan includes:

1. The delivery of all documentation of the Project chosen and the responsibilities of each of the group's members on the specified dates. There are individual and group deliveries, both are clearly defined and planned at the beginning of the four-month period.

2. Delivery of final documentation, presentation and publicly defend the Project by group.

3. Assessment is based on continuous assessment pass mark considering the following premises:

- Individual exams during the academic year (by topics)............25\% of mark

- Individual works during the academic year (by topics)................25\% of mark 
- Group works during the academic year (by topics)..................30\% of mark

- Attendance to theoretical classes and class participation............. 10\% of mark

- Attendance to practices and class participation .................. $10 \%$ of mark

If a minimum of $50 \%$ is not fulfilled in each part and in all topics, students cannot opt for continuous assessment pass mark and they will have to take the final exam, with the corresponding failed part. If they do not opt for the continuous assessment pass mark option, they will need to take the subject's final exam.

In this second stage, the lecturers assess learners' knowledge and provide information as well as facilitate learning. All this roles include helping students grow in understanding, Knowledge, self-awareness, moral development and the ability to relate to others. The introduction of PBL with a consequent fundamental change in the student-teacher relationship has highlighted the change in the role of the teacher from one of information provider to one of facilitator. Now the teacher's role is not to inform the students but to encourage and facilitate them to learn for themselves using the problem as a focus for the learning. This changing role of the teacher is also reflected in the constructivist approach to learning, in which knowledge is 'constructed' in the mind of the student and is constantly evolving. The lecturers who make-up this team teaching, $1 \mathrm{PhD}$ and 2 assistant professors with a wide professional experience, have the ability to communicate with students in an informal way in the small groups sessions, and to encourage student learning by creating an atmosphere in which open exchange of ideas was facilitated.

\subsection{Data collection and analysis}

Firstly the perceptions of the participants in the experience will be analyzed in order to determine students'satisfaction with the quality of educational services (Budic, H. \& Andrilc, 2011). Data were collected at the end of the second quarter through questionnaires which consisted of eleven open-ended questions on the three main following topics: subjects; conditions; and learning experiences. Each of them has been valued by a scale of 1-5. The results obtained are shown in Table-1 (4th year subject) and Table-2 (5th year subject), and at the end of each table the return rate is shown in percentages.

As it can be observed, in the previous year to this educational implantation, the percentage of answers represented over 35\% return rate, whereas in both years of implementation the percentage was increased in a $20 \%$. With these results became apparent that the students are more participative and involved in the experience. Another aspect that comes to the light is that the topics better valued before, on average, is "subject" (3.03 points) but with this new methodology "learning experience" has taken the bank from it with a valuation of 3.58 on average in course 2010/11, which supposes a total increase of 0.57 points. Both "subject" and "learning experience" have increased their valuation in 0.5 points on average, whereas "conditions", that were worse valued at the beginning, has had the greater increase (0.65 points on average) since field courses to factories as trips to singular structures 
under construction are measured that have very good acceptance on part of the students.

\begin{tabular}{|l|c|c|c|}
\hline \multirow{2}{*}{ QUESTIONS } & \multicolumn{3}{|c|}{ VALUATION } \\
\cline { 2 - 4 } & $2008 / 09$ & $2009 / 10$ & $2010 / 11$ \\
\hline 1- Subject & 3.47 & 3.65 & 3.87 \\
\hline A- The subject is important for your education & 3.25 & 3.37 & 3.7 \\
\hline $\begin{array}{l}\text { B- You consider the subject contents of the subject } \\
\text { interesting }\end{array}$ & 2.56 & 2.75 & 3.2 \\
\hline $\begin{array}{l}\text { C- The objectives and the extension of the subject } \\
\text { program are in agreement to teaching hours }\end{array}$ & 2.85 & 2.98 & 3.44 \\
\hline D- The program and the bibliography are updated & 2.95 & 3.2 & 3.57 \\
\hline 2- Conditions: space, equipment, material, student... & 2.5 & 3.11 \\
\hline E- They are suitable for the theoretical classes & 3.17 & 3.49 & 3.61 \\
\hline F- They are suitable for the practical classes & 2.98 & 3.33 & 3.7 \\
\hline 3- Learning experience & 3 & 3.16 & 3.55 \\
\hline G- Teaching / learning process & 2.9 & 3.07 & 3.47 \\
\hline H- Educational environment & 2.4 & 2.7 & 2.7 \\
\hline I- Learning experience & $32 \%$ & $57.92 \%$ & $56.10 \%$ \\
\hline J- Learning methodology & \multicolumn{3}{|c|}{} \\
\hline K- Assessment & & \\
\hline RETURN RATE (\%) &
\end{tabular}

Tab. 1. Structural Theory and Industrial Structures

\begin{tabular}{|l|c|c|}
\hline \multirow{2}{*}{ QUESTIONS } & \multicolumn{2}{c|}{ VALUATION } \\
\cline { 2 - 3 } & $2009 / 10$ & $2010 / 11$ \\
\hline 1- Subject & 3.65 & 3.59 \\
\hline A- The subject is important for your education & 3.23 & 3.42 \\
\hline $\begin{array}{l}\text { B- You consider the subject contents of the subject } \\
\text { interesting }\end{array}$ & 2.86 & 3.26 \\
\hline $\begin{array}{l}\text { C- The objectives and the extension of the subject program } \\
\text { are in agreement to teaching hours }\end{array}$ & 2.78 & 3.45 \\
\hline D- The program and the bibliography are updated & 2.87 & 3.48 \\
\hline 2- Conditions: space, equipment, material, student... & 2.92 & 3.28 \\
\hline E- They are suitable for the theoretical classes & 2.83 & 3.53 \\
\hline F- They are suitable for the practical classes & 3.12 & 3.75 \\
\hline 3- Learning experience & 2.72 & 3.37 \\
\hline G- Teaching / learning process & 2.65 & 3.29 \\
\hline H- Educational environment & 2.92 & 2.63 \\
\hline I- Learning experience & $39 \%$ & $51.74 \%$ \\
\hline J- Learning methodology & \multicolumn{2}{|l}{} \\
\hline K- Assessment &
\end{tabular}

Tab. 2. Engineering Projects 
For the 5th year subject (Table-2), "subject" is the best one valued in both cases (3.43 points in course 2010/11) for being a subject in great agreement with their professional future that supposes the last passage towards their degree. Nevertheless it is worthy of mention the fact that the greater increase on average is "learning experience" with 0.54 points. This result shows the total agreement of the students with new implanted PBL methodology. With the intention to make more evident the results, Figures $4 \mathrm{a}$ and $4 \mathrm{~b}$ show the graphics of the students's surveys.

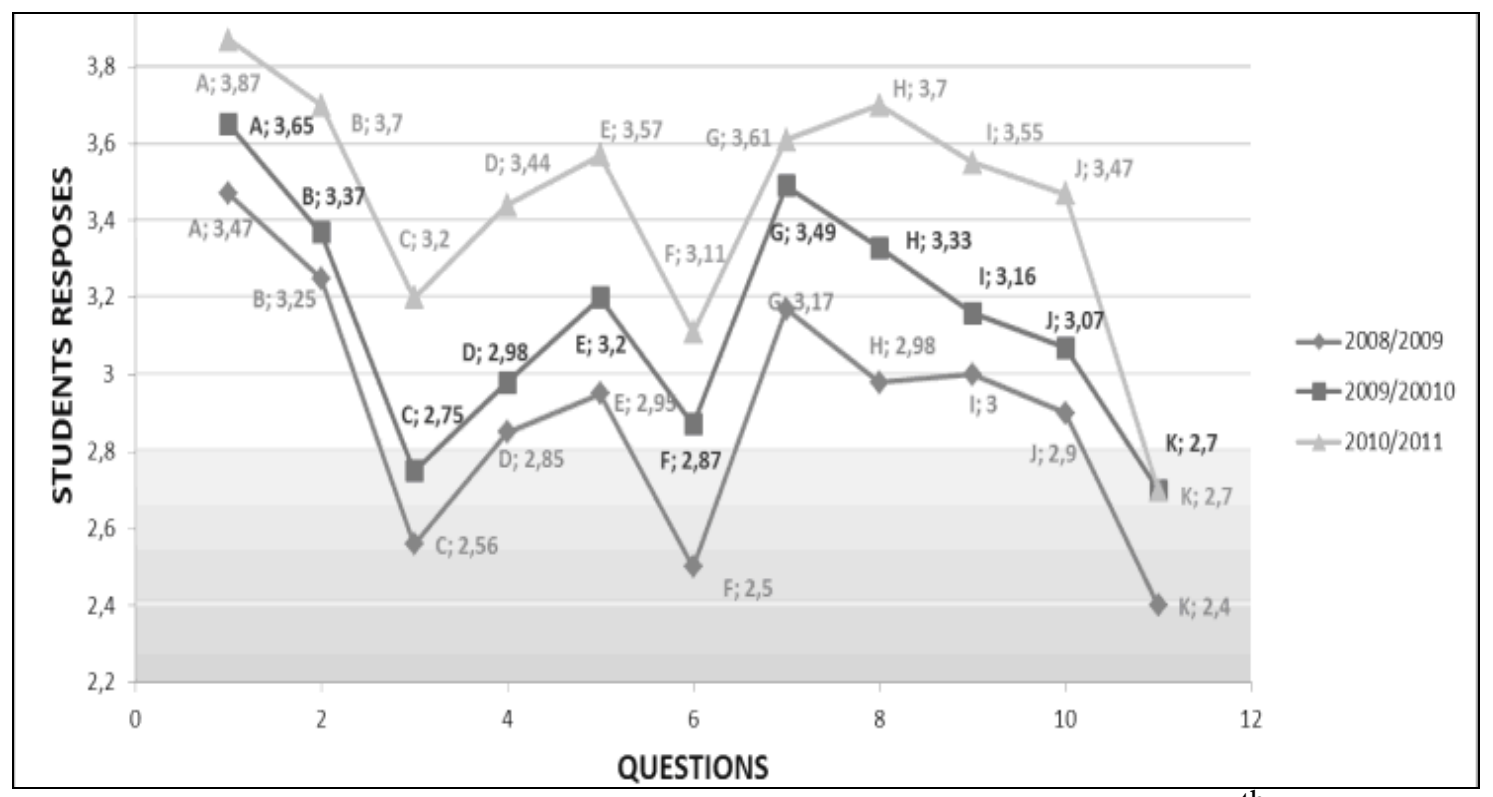

Fig. 4a. Graphics with the results from the students' surveys of the $4^{\text {th }}$ year subject

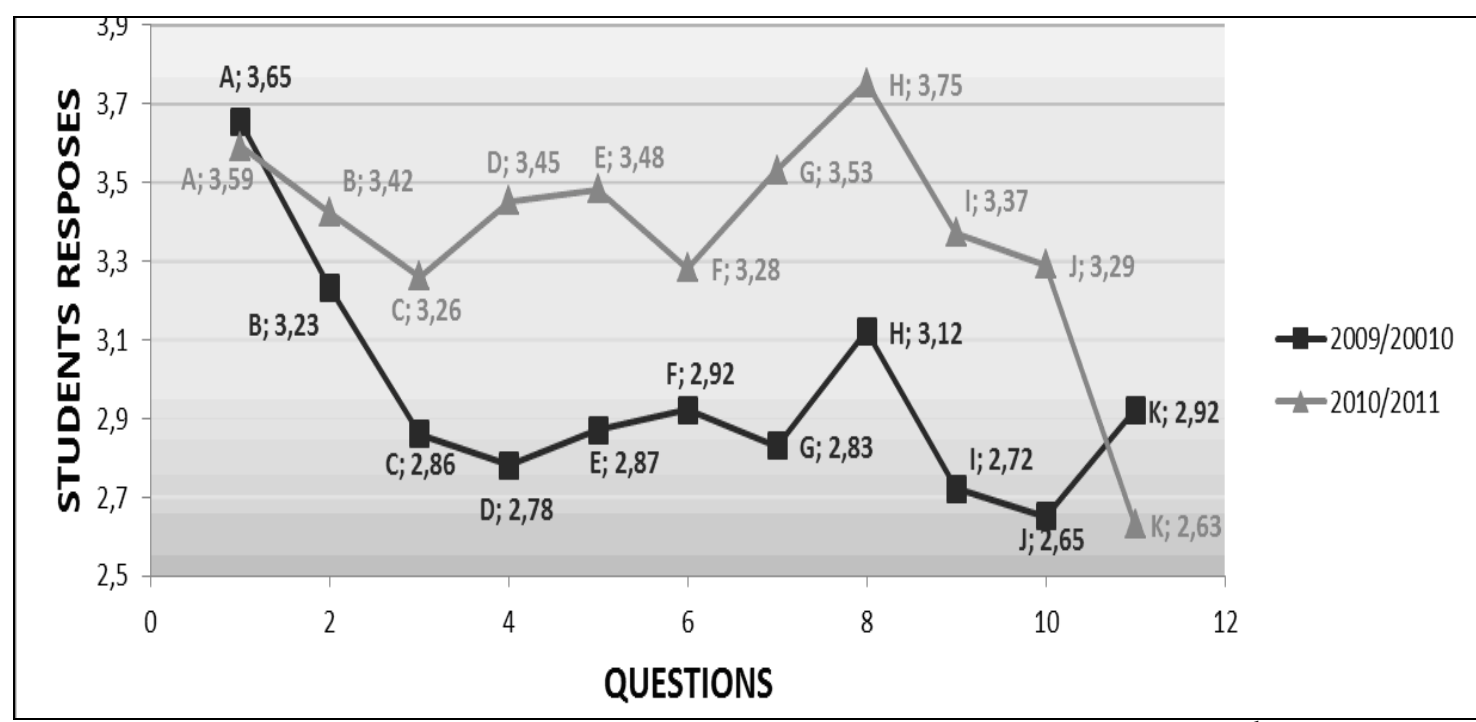

Fig. 4b. Graphics with the results from the students' surveys of the $5^{\text {th }}$ year subject

Immediately after, the academic results of both subjects achieved in this interdisciplinary project approach will be analyzed (Fernandes, Lima, Cardoso, Leão, Flores, 2009). Table 3 represents a set of evaluation indicators that were selected for this study: the ratio of students assessed to those enrolled in the course, the ratio of students approved to those enrolled in the course, the ratio of students approved to those assessed in the course. Such as it is revealed, the number of students in each 
subject varies from course to course. A student is considered approved with a grade higher or equal to 5 out of 10 . The ratios presented show results that are more favourable for the new methodology in the two subjects, and for the three academic years. In particular, for "engineering projects" subject, the ratio assessed/enrolled presents values above $94.11 \%$, whereas in the previous year the value is below $65.35 \%$. Similarly, for "Structural Theory and Industrial Structures" subject the ratio approved/assessed increased from $5 \%$ to $10 \%$ the first year of implantation.

\begin{tabular}{|c|c|c|c|c|c|}
\hline Years & $\begin{array}{l}\text { Number } \\
\text { students }\end{array}$ & $\begin{array}{c}\text { 4th } \\
\text { year } \\
\text { subject }\end{array}$ & $\begin{array}{c}5 \text { th } \\
\text { year } \\
\text { subject }\end{array}$ & $\begin{array}{c}\text { Ratios } \\
\text { (4th year subject) }\end{array}$ & $\begin{array}{c}\text { Ratios } \\
\text { (5th year subject) }\end{array}$ \\
\hline \multirow[t]{3}{*}{$2008 / 9$} & Enrolled & 330 & ---- & ass./enr. $=38.48 \%$ & ---- \\
\hline & Assessed & 127 & ---- & app./enr.=21.21\% & ---- \\
\hline & Approved & 70 & --- & app./ass. $=54.6 \%$ & ---- \\
\hline \multirow{3}{*}{$\begin{array}{c}2009 / 1 \\
0\end{array}$} & Enrolled & 351 & 127 & ass./enr. $=57.83 \%$ & ass./enr. $=74 \%$ \\
\hline & Assessed & 203 & 94 & app./enr. $=42.16 \%$ & app./enr. $=65.35 \%$ \\
\hline & Approved & 148 & 83 & app./ass. $=72.91 \%$ & app./ass. $=88.3 \%$ \\
\hline \multirow{3}{*}{$\begin{array}{c}2010 / 1 \\
1\end{array}$} & Enrolled & 318 & 102 & ass./enr. $=58.49 \%$ & ass./enr. $=95 \%$ \\
\hline & Assessed & 186 & 97 & app./enr.=36.8\% & app./enr.=94.11\% \\
\hline & Approved & 117 & 96 & app./ass.=62.9\% & app./ass. $=98.97 \%$ \\
\hline
\end{tabular}

Tab. 3. Grade analysis for the three academic years (2008/09 to 2010/11)

\section{Conclusion}

On the basis that this research is limited, first by the fact that the initiative has started directly from teachers with the resources that were available (effort, time, budget, materials, collaborating companies,...), second by the intrinsic difficulty that entails the implantation of Group Techniques where the main problem lies in the relations between the people, and third by the difficult coordination between the different areas and departments involved in, the collaboration approach reported by the authors represents a different rationale for collaboration, namely integrated curriculum among traditional subjects. Curriculum integration was proposed in a contrast to the conventional university subjects.

From the authors point of view, one of the most important reasons for curriculum integration is the disconnection between a discipline-based curriculum and the real world. Through this process, students are exposed to real-life structural design problems, understanding that the structure is not a separate issue, only subject to the principles of rational mechanics, but that there are external conditioning functional, economic or aesthetic factors, that are at least as important as, or even more important than those solely structural, and have to be considered. On the other hand, the fact of having field courses in unique plant premises and construction sites, 
allows the student to personally observe some of the studied structural typologies and mechanical systems.

Surely the most crucial part is the project's tutored work because the most effective way to learn to solve a problem is to face it. Here students take the lead. Logically, there are numerous difficulties and teacher's collaboration helps them solve most of the problems, but the most important thing is that the student becomes aware of difficulties and at least the first time he is given support to face them.

The main teaching improvements applied to these disciplines have been:

1.Provide a clearly practical and applied approach, basic in the technological subjects of Industrial Engineering final years.

2.Put students in contact with the professional activity that they will carry out in the near future.

3.Increase student motivation, mainly by means of field courses and the use of professional software.

4.Fostering teacher-student relationship and interaction.

5.Confer a unifying nature. Not regarding subjects as watertight compartments, since professional reality brings about questions that are commonly interdisciplinary.

6.Design 3-hour lab working sessions, enabling students to be concentrated in the problem longer; this takes students to the professional world reality, where matters are not changed every hour. This allows for changing tasks (group meetings, individual work, and interviews with lecturers).

The main disadvantages found have been:

1.To have the budget necessary to buy the software.

2.Less time for the traditional knowledge passed on in the classroom.

3. The student must be able to work with others, is not suitable for those who are enclosed in themselves to learn.

4.It requires more effort, students tend to employ more time for these activities each week compared with other education systems.

5. Teachers must be willing to try new ways and be aware that they also need to learn.

In spite of everything, the results obtained have been excellent, mainly in the 5 th year subject, with a presence and success rate close to $99 \%$. The percentage of students that did not take the exam is in line with the number of students that do not follow the continuous assessment procedure (continuous assessment pass mark). In view of the success of this initiative, the university has bought the Campus version for the next academic year: it has been specially designed to be used in university public networks which function under Eduroam1 (education roaming), as do numerous Universities worldwide (Europe, Canada, USA, and some countries in Asia and Oceania such as China, Japan, Australia or New Zealand). The Campus version allows for CYPE programs and modules to be executed with a University for a specific time, usually one academic course. To be able to use the programs, a 
password, provided by CYPE or the University must be introduced, as well as having a permanent broadband internet connection.

Founded in the results, the innovation and adaptation to new teaching methodologies in the Structures Engineering Area presented in this paper are beneficial, appropriate, and is a preliminary attempt to fit the needs of the newly university integrated curriculum scheme. The experience preserves the teacher abilities achieved to integrate theory and practice, design technology-based syllabus, and adopt strategies, thus successfully practiced in this teaching demonstration. Future research may consider to use other methods to verify or confirm the value of such a type of collaboration and generate deeper understanding of the issue.

\section{Acknowledgements}

In this space, we want to express our gratitude to the company Castelo Soluciones Estructurales, S.L.L. for his unselfish work in the support, diffusion and collaboration in the education of professional futures, and to the teachers from the School of Industrial Engineering for their initiative and dedication.

\section{References}

Budic, H. \& Andrlic, B. (2011). Measuring students'satisfaction and its importance for improving marketing mix of services in higher education, Proceedings of 22nd International DAAAM Symposium, Katalinic, B. (Ed.), pp. 61-62, ISBN 978-3-901509-83-4, Vienna, November 2011 DAAAM International, Viena Buckley, F.J. (2000). Team Teaching: What, Why and How. Sage Publications Inc., ISBN-0-7619-0744-0,California

Chang, L-C. \& Lee, G.C. (2010). A team-teaching model for practicing project-based learning in high school: Collaboration between computer and subject teachers. Computers \& Education, Vol. 55, No. 3, November 2010, pp. 961-969, http://dx.doi.org/10.1016/j.compedu.2010.04.007

Collis, B. (1998). WWW-based environments for collaborative group work. Education and Information Technologies, Vol. 3, No.3-4, pp. 231-245, ISSN 1360-2357

Dugan, K. (2008). Student appraisals of collaborative teaching. College Teaching, Vol. 56, No. 1, winter 2008, pp. 11-15, ISSN 8756-7555

English, S., \& Yazdani, M.(1999). Computer-supported cooperative learning in a virtual university. Journal of Computer Assisted Learning, Vol. 15, No. 2, pp. 2-13, ISSN 1365-2729

Fernandes, S., Lima, R.M., Cardoso, E., Leão, C.P., Flores, M.A. (2009). An Academic Results Analysis of a First Year Interdisciplinary Project Approach to Industrial and Management Engineering Education. Proceedings of the PAEE'2009, pp. 149-156, Guimarães-Portugal, July 2009 
Goicoechea, I. \& Fenollera, M. (2011). Education based on competences: virtual learning and project-based learning, Chapter 14 in DAAAM International Scientific Book 2011, pp. 165-180, B. Katalinic (Ed.), Published by DAAAM International, ISSN 1726-9687, Vienna, Austria

Heitmann, G. (2005). Challenges of Engineering Education and Curriculum Development in the Context of the Bologna Process. European Journal for Engineering Education, Vol. 30, No. 4, pp. 447-458, ISSN 0304-3797

Helle, L., Tynjälä, P., \& Olkinuora, E. (2006). Project-based learning in postsecondary education - theory, practice and rubber sling shots. Higher Education, Vol. 51, No. 2, pp. 287-314. DOI: 10.1007/s10734-004-6386-5

Kulynych, J.J. (1998). Crossing disciplines: Postmodernism and democratic education. College Teaching, Vol. 46, No. 4, pp. 144-149, ISSN 8756-7555.

Perry, B. \& Stewart, T. (2005). Insights into effective partnership in interdisciplinary team teaching. System, Vol. 33, No 4, December 2005, pp. 563-573, DOI http://dx.doi.org/10.1016/j.system.2005.01.006

Popescu, A-I. (2011). Transforming learning for lifelong learning in the knowledge economy, Proceedings of 22nd International DAAAM Symposium, Katalinic, B. (Ed.), pp. 61-62, ISBN 978-3-901509-83-4, Vienna, November 2011 DAAAM International, Viena, Austria

Sandholtz, J. H. (2000). Interdisciplinary team teaching as a form of professional development. Teacher Education Quarterly, Vol. 27, No. 3, July 2000, pp. 3950, ISSN 0737-5328

Syh-Jong, J. (2008). Innovations in science teacher education: effects of integrating technology and team-teaching strategies. Computers \&Education, Vol.51, No.2, Sept. 2008, pp. 646-659, http://dx.doi.org/10.1016/j.compedu.2007.07.001

Villa, R. A., Thousand, J. S., \& Nevin, A. I. (2008). Co-Teaching: A Multimedia Kit For Professional Development. Corwin Press, ISBN 9781412954846

Walther-Thomas, C., Brtant, M., \& Land, S. (1996). Planning for effective co teaching: The key to successful inclusion. Remedial and Special Education, Vol.17, No. 4, July 1996, pp. 255-265, ISSN 0741-9325

Welch, M., \& Sheridan, S. M. (1995). Educational partnerships: Serving students at risk. Fort Worth, TX: Harcourt Brace, ISBN: 0155009540, United States

*** http://ond.vlaanderen.be/hogeronderwijs/bologna/- Communiqué of the Conference of European Ministers Responsible for Higher Education: The Bologna Process 2020- The European Higher Education Area in the new decade. (2009) Leuven and Louvain-la-Neuve, Accesed on : 2012-09-06 